\title{
Spring Clipping, Fire, and Simulated Increased Atmospheric Nitrogen Deposition Effects on Tallgrass Prairie Vegetation
}

\author{
Alexander J. Smart, ${ }^{1 *}$ Tabithia K. Scott, ${ }^{2}$ Sharon A. Clay, ${ }^{3}$ David E. Clay, ${ }^{3}$ Michelle Ohrtman, ${ }^{4}$ and \\ Eric M. Mousel ${ }^{5}$
}

Authors are ${ }^{1}$ Professor, Department of Natural Resource Management, SDSU, Brookings, SD 57007, USA; ${ }^{2}$ Soil Conservationist, USDA-NRCS, Madison, SD 57042, USA; ${ }^{3}$ Professor and ${ }^{4}$ Postdoctoral Researcher, Department of Plant Sciences, SDSU, Brookings, SD 57007, USA; and ${ }^{5}$ Extension Cow-Calf Specialist, North Central Research and Outreach Center, University of Minnesota, Grand Rapids, MN 55744, USA.

\begin{abstract}
Defoliation aimed at introduced cool-season grasses, which uses similar resources of native grasses, could substantially reduce their competitiveness and improve the quality of the northern tallgrass prairie. The objective was to evaluate the use of early season clipping and fire in conjunction with simulated increased levels of atmospheric nitrogen deposition on foliar canopy cover of tallgrass prairie vegetation. This study was conducted from 2009 to 2012 at two locations in eastern South Dakota. Small plots arranged in a split-plot treatment design were randomized in four complete blocks on a warm-season grass interseeded and a native prairie site in east-central South Dakota. The whole plot consisted of seven treatments: annual clip, biennial clip, triennial clip, annual fire, biennial fire, triennial fire, and undefoliated control. The clip plots consisted of weekly clipping in May to simulate heavy grazing. Fire was applied in late April or early May. The subplot consisted of nitrogen applied at 0 or $15 \mathrm{~kg} \mathrm{~N} \cdot \mathrm{ha}^{-1}$ in early June. All treatments were initially applied in 2009 . Biennial and triennial treatments were reapplied in 2011 and 2012, respectively. Canopy cover of species/major plant functional groups was estimated in late August/ early September. Annual clipping was just as effective as annual fire in increasing native warm-season grass and decreasing introduced cool-season grass cover. Annual defoliation resulted in greater native warm-season grass cover, less introduced coolseason grass cover, and less native cool-season grass cover than biennial or triennial defoliation applications. Low levels of nitrogen did not affect native warm-season grass or introduced cool-season cover for any of the defoliation treatments, but it increased introduced cool-season grass cover in the undefoliated control at the native prairie site. This study supports the hypothesis that appropriately applied management results in consistent desired outcomes regardless of increased simulated atmospheric nitrogen depositions.
\end{abstract}

Key Words: big bluestem, burning, introduced grasses, mowing, native grasses, nitrogen

\section{INTRODUCTION}

Remaining portions of tallgrass prairie in the Great Plains of North America are highly fragmented and invaded by introduced cool-season grasses (Howe 1994a; Smith and Knapp 1999; Cully et al. 2003; Vinton and Goergen 2006). Introduced cool-season grasses invade tallgrass prairie communities because they start growing earlier in the season than the warm-season grasses, which often dominate native prairie vegetation (Collins and Gibson 1990). The early season growth of cool-season grasses is a competitive advantage, allowing capture of light, nitrogen, and moisture before the native warm-season tallgrass species start growing (Diboll 1984; Vinton and Goergen 2006). In addition, smooth bromegrass (Bromus inermis Leyss. subsp. inermis) has been shown to have a lower C:N ratio and higher decomposition rate than warm season grasses, which gives it at a competitive advantage in nitrogen cycling (Vinton and Goergen 2006).

Fire has been used to suppress introduced cool-season grasses and improve native vegetation quality. Late-spring fires are particularly effective at reducing cool-season grasses and

Correspondence: Alexander J. Smart, Dept of Natural Resource Management, SDSU, Brookings, SD 57007, USA. Email: Alexander.smart@sdstate.edu

Manuscript received 3 April 2013; manuscript accepted 19 July 2013.

(c) 2013 The Society for Range Management increasing warm-season production (Howe 1994b, 1995, 2000). Implementing burns in late spring injures introduced cool-season species and promotes warm-season species by a variety of mechanisms (Diboll 1984, Mitchell et al. 1996). The frequency of fire can also influence competition between cooland warm-season grasses. For example, repeated annual burns during elongation, heading, and flowering were most effective at reducing smooth bromegrass tiller density and biomass (Willson and Stubbendieck 2000). However, conditions in the northern Great Plains often do not offer a wide window of opportunity to conduct late-spring burns. Wet weather, low fuel loads, and excessive amounts of green vegetation (low dead to live ratio) prevent prescribed fires from effectively burning and consuming biomass. Incomplete burns would provide only partial control of undesirable species and may fail to achieve management objectives.

Grazing and mowing are alternative methods that can be used for early season defoliation to shift dominance from coolseason to warm-season grass species when conditions are unfavorable for burning. However, similar to prescribed fire, the success of grazing or mowing for reducing cool-season grass cover is dependent on timing. A comparison in eastern Nebraska revealed that spring mowing favored big bluestem (Andropogon gerardi Vitman), a native warm-season grass, while summer mowing promoted porcupine grass (Hesperostipa spartea [Trin.] Barkworth), a native cool-season bunch grass (Hover and Bragg 1981). In South Dakota repeated years 
of short-interval intensive fall and spring grazing events reduced competition from introduced cool-season grass species and increased established populations of perennial warmseason grasses (Smart and Owens 2008).

Mixed responses of native and introduced forbs to defoliating disturbance are often reported because forbs vary in life form and season of growth (Grace et al. 2001). Generally, in native prairie sites, long-term burning reduces forb biomass compared with unburned prairie (Towne and Owensby 1984). Likely many invasive forb species that are prolific seed producers and resprouters, such as introduced forbs, are usually unharmed or actually increase with fire (Grace et al. 2001).

Species composition in native, warm-season tallgrass prairies also is influenced by atmospheric nitrogen deposition or fertilization. Nitrogen is one of the main factors that limit native tallgrass prairie production in disturbed prairies (Tilman and Wedin 1991; Anderson et al. 2006). Mitchell et al. (1996) reported that $67 \mathrm{~kg} \mathrm{~N} \cdot \mathrm{ha}^{-1}$ applied in May increased big bluestem production on remnant native prairie. However, Vinton and Goergen (2006) found that nitrogen applied in small increments over $2 \mathrm{yr}$ (April/June/September/May/June applications) increased smooth bromegrass tiller density and biomass and failed to enhance switchgrass (Panicum virgatum L.) growth on a restored eastern Nebraska tallgrass prairie. Other studies have revealed that small changes in nitrogen availability $\left(10-20 \mathrm{~kg} \mathrm{~N} \cdot \mathrm{ha}^{-1}\right)$ enable introduced cool-season grasses to outcompete native species and reduce prairie grassland diversity (Tilman 1990; Clark and Tilman 2008). In eastern South Dakota, annual inorganic nitrogen wet deposition was approximately $4.5 \mathrm{~kg} \mathrm{~N} \cdot \mathrm{ha}^{-1}$ in 2009 (NADP 2010) and is expected to increase to $10-20 \mathrm{~kg} \mathrm{~N} \cdot \mathrm{ha}^{-1}$ in this region over the next $50 \mathrm{yr}$ (Clark and Tilman 2008). However, it is unclear how this projected nitrogen deposition will impact traditional management practices, grassland community composition, and functional species cover.

Previous research has examined a single defoliation treatment or a combination of two (i.e., fire, herbicide, mowing) in conjunction with fertilizer application to reduce the influence of introduced cool-season grasses in tallgrass prairie (Owensby and Smith 1979; Samson and Moser 1982; Gillen et al. 1987; Masters et al. 1992; Mitchell et al. 1996; Collins et al. 1998). In most cases mowing was done once to simulate a hay harvest (Hover and Bragg 1981; Collins et al. 1998; Prober et al. 2008). These short-term studies did not evaluate the impact of reapplying these treatments at different frequencies.

Our study incorporated defoliation treatments, spring burning and repeated intensive clipping (a surrogate for grazing) in late spring, in conjunction with low-level nitrogen fertilization to simulate increased atmospheric deposition of inorganic nitrogen, to test the effects on canopy cover of introduced cool-season grasses, native warm-season grasses, native cool-season grasses, and introduced and native forbs. We also examined defoliation treatment frequency on an annual, biennial, or triennial schedule. We hypothesized that 1) repeated clipping during the month of May, when introduced cool-season grasses are in their rapid growth phase, would be equal to the effect of spring burning in reducing introduced cool-season grass and increasing native warm-season grass canopy cover, 2) annual applications of defoliation treatments would have a greater impact on canopy cover than either biennial or triennial applications, 3) native cool-season grasses would be negatively impacted by annual defoliation treatments, 4) introduced and native forbs would be unaffected by defoliation treatments, and 5) low-level nitrogen application in early summer would increase warm-season grass cover and decrease introduced cool-season grass cover with respect to disturbance.

\section{METHODS}

\section{Site Description}

The northern Great Plains has a continental climate, characterized by cold winters and hot summers. The growing season in South Dakota typically occurs from April to September. Approximately $75 \%$ of the annual precipitation is received during this time (Gartner and Sieg 1996). Two study sites were established in eastern South Dakota on pastures owned by South Dakota State University with exclosure fences constructed around the perimeter of each site.

Interseeded Site. The interseeded site (lat $44^{\circ} 20^{\prime} 6.33^{\prime \prime} \mathrm{N}$, long $96^{\circ} 48^{\prime} 28.62^{\prime \prime} \mathrm{W}$ ) is located in Brookings County approximately $1 \mathrm{~km}$ north of Brookings, South Dakota. It is an introduced cool-season pasture and hay field that was interseeded with big bluestem in 2005. The soil is a well-drained Barnes clay loam (fine-loamy, mixed Calcic Hapludolls) with $0-2 \%$ slopes receiving a mean annual precipitation of $604 \mathrm{~mm}$ (USDA NRCS 2013a, 2013b). Average annual temperatures range from $3.9^{\circ} \mathrm{C}$ to $7.2^{\circ} \mathrm{C}$ with an average frost-free period of 120 to 160 days. The ecological site description is loamy with loamy till parent material. The dominant species were big bluestem, smooth bromegrass, and Kentucky bluegrass (Poa pratensis L.).

Native Prairie Site. The native prairie site (long $44^{\circ} 23^{\prime} 1.53^{\prime \prime} \mathrm{N}$, lat $\left.96^{\circ} 57^{\prime} 29.39^{\prime \prime} \mathrm{W}\right)$ is located upslope from a wetland in Brookings County approximately $6 \mathrm{~km}$ north and $11 \mathrm{~km}$ west of Brookings, South Dakota. Prevalent cool-season grasses included green needlegrass (Nassella viridula [Trin.] Barkworth) and porcupine grass. Warm-season grasses included little bluestem (Schizachyrium scoparium [Michx.] Nash), sideoats grama (Bouteloua curtipendula [Michx.] Torr.), and big bluestem. Introduced cool-season grasses included smooth bromegrass and Kentucky bluegrass. Predominant native forbs included solidago sp. and aster sp. Introduced forbs included Canada thistle (Cirsium arvense [L] Scop.), musk thistle (Carduus nutans L.), and yellow sweet clover (Melilotus officinalis [L.] Lam.). Native shrubs included western snowberry (Symphoricarpos occidentalis Hook.) and prairie rose (Rosa arkansana Porter). The soil is classified as a Buse-Poinsett complex (fine-loamy, mixed Typic Calciudolls and fine-silty, mixed Calcic Hapludolls) with 9-15\% slopes (USDA NRCS 2013a; 2013b). It is well drained, and the ecological site description is thin loamy to loamy with loamy till and silty drift over loamy till parent material.

\section{Experimental Design}

This study used a randomized complete block design with four replications at the two experiment sites. The whole plot $(3 \times 6$ 
Table 1. Average monthly precipitation for 2009-2012 and the 30-yr average (1971-2000) for Brookings, South Dakota (HPRCC 2012).

\begin{tabular}{|c|c|c|c|c|c|}
\hline Month & 2009 & 2010 & 2011 & 2012 & $1971-2000$ \\
\hline & \multicolumn{5}{|c|}{-Precipitation $(\mathrm{mm})$} \\
\hline April & 22 & 31 & 33 & 60 & 52 \\
\hline May & 57 & 56 & 111 & 161 & 75 \\
\hline June & 84 & 202 & 85 & 43 & 107 \\
\hline July & 96 & 134 & 106 & 32 & 79 \\
\hline August & 35 & 121 & 34 & 50 & 75 \\
\hline Total & 294 & 545 & 369 & 345 & 388 \\
\hline
\end{tabular}

m) consisted of annual clip, biennial clip, triennial clip, annual fire, biennial fire, triennial fire, and an undefoliated control. The subplot $(3 \times 3 \mathrm{~m})$ consisted of nitrogen applied at 0 or 15 $\mathrm{kg} \mathrm{N} \cdot \mathrm{ha}^{-1}$ in early June each year throughout the study period.

\section{Treatments}

All defoliation treatments were initially applied in 2009, biennial treatments were reapplied in 2011, and triennial treatments were reapplied in 2012. Repeated clipping was used to simulate intensive early season grazing. The clipping treatment was done every week in May to the appropriate areas by mowing the vegetation to a height of $5 \mathrm{~cm}$ using a rearbag push mower with a $0.53 \mathrm{~m}$ swath. Clippings were removed from the plots.

A single fire treatment was applied by burning the vegetation on the whole plots on 22 April 2009, 27 April 2010, 6 May 2011, and 9 May 2012 at the interseeded sites and on 11 May 2009, 5 May 2010, 6 May 2011, and 9 May 2012 at the native prairie site. A drip torch filled with a 1:1 mixture of diesel and gasoline was used to ignite the vegetation, and backpack pumps filled with water were used for fire containment. A ring fire technique was used to burn the plots. The prescribed weather conditions were $8-30 \mathrm{kph}$ wind speed, $10-29^{\circ} \mathrm{C}$ temperature, and $20-50 \%$ relative humidity. We strictly adhered to the limits of this prescription.

The $15 \mathrm{~kg} \mathrm{~N} \cdot \mathrm{ha}^{-1}$ treatment was applied as granular ammonium sulfate (AMS) on 4 June 2009 and 5 June 2010. In 2011 and 2012, granular urea was used instead and fertilized on 4 June each year. The granules were distributed by sprinkling the material across each plot using plastic cups with holes drilled in the lids. The AMS and urea was sieved before use, so particles were similar sized to attain an even

Table 2. Average monthly temperature for 2009-2012 and the 30-yr average (1971-2000) for Brookings, South Dakota (HPRCC 2012).

\begin{tabular}{|c|c|c|c|c|c|}
\hline Month & 2009 & 2010 & 2011 & 2012 & $1971-2000$ \\
\hline & \multicolumn{5}{|c|}{-Temperature $\left({ }^{\circ} \mathrm{C}\right)$} \\
\hline April & 6 & 11 & 6 & 9 & 7 \\
\hline May & 14 & 14 & 13 & 16 & 14 \\
\hline June & 18 & 19 & 19 & 22 & 19 \\
\hline July & 19 & 22 & 24 & 25 & 22 \\
\hline August & 19 & 23 & 21 & 20 & 20 \\
\hline Average & 15 & 18 & 17 & 18 & 16 \\
\hline
\end{tabular}

Table 3. Source of variation and $P$ values from ANOVA on foliar cover of big bluestem (BB), introduced cool-season grass (ICG), introduced forb $(\mathrm{IF})$, native warm-season grass (NWG), native cool-season grass (NCG), and native forb (NF) at the interseeded and native prairie sites, in eastcentral South Dakota from 2009 to 2012.

\begin{tabular}{|c|c|c|c|c|c|c|c|c|}
\hline \multirow{2}{*}{$\begin{array}{l}\text { Source of } \\
\text { variation }\end{array}$} & \multicolumn{3}{|c|}{ Interseeded site } & \multicolumn{5}{|c|}{ Native prairie site } \\
\hline & BB & ICG & IF & NWG & ICG & NCG & IF & NF \\
\hline \multicolumn{9}{|l|}{ Defoliation } \\
\hline treatment (D) & 0.01 & 0.02 & 0.43 & $<0.01$ & $<0.01$ & 0.02 & 0.02 & 0.05 \\
\hline Nitrogen (N) & 0.89 & 0.78 & 0.84 & 0.86 & 0.86 & 0.81 & 0.59 & 0.04 \\
\hline $\mathrm{D} \times \mathrm{N}$ & 0.79 & 0.74 & 0.02 & 0.59 & 0.03 & 0.66 & 1.00 & 0.07 \\
\hline Year $(Y)$ & $<0.01$ & $<0.01$ & $<0.01$ & $<0.01$ & $<0.01$ & 0.01 & $<0.01$ & $<0.01$ \\
\hline$D \times Y$ & 0.02 & $<0.01$ & 0.17 & $<0.01$ & $<0.01$ & 0.01 & $<0.01$ & $<0.01$ \\
\hline$N \times Y$ & 0.70 & 0.68 & 0.99 & 0.92 & 0.86 & 0.22 & 0.99 & 0.84 \\
\hline $\mathrm{D} \times \mathrm{N} \times \mathrm{Y}$ & 1.00 & 0.99 & 0.99 & 0.92 & 0.17 & 0.85 & 1.00 & 0.69 \\
\hline
\end{tabular}

application. We recognize that a single application (pulse dose of fertilization) does not represent a chronic increase in atmospheric $\mathrm{N}$ deposition. However, the June application is when about $60 \%$ of the rainfall has occurred for a typical growing season (Table 1) and therefore corresponds to peak atmospheric deposition of $\mathrm{N}$ with rainfall (Köchy and Wilson 2001; NADP 2010) and also corresponds to agriculture fertilizing activity (Zhao et al. 2009).

\section{Sampling}

Percent canopy cover of species or major plant functional groups was determined using a $1-\mathrm{m}^{2}$ quadrat placed in the center of each sub-subplot (buffered by $1-\mathrm{m}^{2}$ on all sides). At the interseeded site, the groups included big bluestem, introduced grasses (Kentucky bluegrass and smooth bromegrass), and introduced forbs. No native cool-season grasses or native forbs were present. At the native prairie site, the functional groups included native warm-season grasses, introduced cool-season grasses, native cool-season grasses, introduced forbs, and native forbs. Shrubs were grouped together with native forbs. Canopy cover estimates were made near peak season standing crop for warm-season species at the interseeded site on 25 August 2009, 23 August 2010, 26 August 2011, and 23 August 2012, and at the native prairie site on 3 September 2009 and 25 August 2010, 24 August 2011, and 3 September 2012.

\section{Statistical Analyses}

A three-way ANOVA was used to test the effects of defoliation treatment, nitrogen application, and year on percent canopy cover of species/major plant functional groups. Year was considered a repeated measure, and the compound symmetry model adequately accounted for error correlation among years. Block and the whole plot error term were considered random effects, whereas defoliation treatment, nitrogen application, and year were considered fixed effects. Sites were analyzed separately because they differed by soil type, slope, ecological site, and plant community (interseeded or native). Treatment effects were significant when $P \leq 0.05$. Least squares means were separated using the PDIFF option (SAS Institute 2008). 
Table 4. Defoliation treatment by year interaction for canopy cover of big bluestem (BB), introduced cool-season grass (ICG), introduced forb (IF), native warm-season grass (NWG), native cool-season grass (NCG), and native forb (NF) at the interseeded and native prairie sites, in east-central South Dakota from 2009 to 2012.

\begin{tabular}{|c|c|c|c|c|c|c|c|c|}
\hline \multirow[b]{2}{*}{ Defoliation treatment } & \multicolumn{3}{|c|}{ Interseeded site } & \multicolumn{5}{|c|}{ Native prairie site } \\
\hline & $\mathrm{BB}$ & ICG & IF & NWG & ICG & NCG & IF & NF \\
\hline \multicolumn{9}{|l|}{2009} \\
\hline Annual clip & $40 a^{1}$ & $59 \mathrm{c}$ & $0 \mathrm{a}$ & $37 a b$ & $18 a b$ & $1 \mathrm{c}$ & $5 a$ & $8 \mathrm{a}$ \\
\hline Biennial clip & $45 \mathrm{a}$ & $56 \mathrm{c}$ & $0 \mathrm{a}$ & $35 a b$ & $16 a b$ & $6 \mathrm{a}$ & $5 a$ & $7 \mathrm{a}$ \\
\hline Triennial clip & $28 a b c$ & $72 a b c$ & $0 \mathrm{a}$ & $26 \mathrm{~b}$ & $23 \mathrm{a}$ & $4 a b$ & $6 \mathrm{a}$ & $8 \mathrm{a}$ \\
\hline Annual fire & $34 \mathrm{ab}$ & $66 \mathrm{bc}$ & $0 \mathrm{a}$ & $35 a b$ & $18 a b$ & $5 a b$ & $4 \mathrm{a}$ & $6 \mathrm{a}$ \\
\hline Biennial fire & $19 \mathrm{bc}$ & $81 \mathrm{ab}$ & $0 \mathrm{a}$ & $42 \mathrm{a}$ & $12 \mathrm{~b}$ & $3 \mathrm{bc}$ & $2 \mathrm{a}$ & $10 \mathrm{a}$ \\
\hline Triennial fire & $12 \mathrm{c}$ & $88 \mathrm{a}$ & $0 \mathrm{a}$ & $37 a b$ & $18 a b$ & $3 \mathrm{bc}$ & $4 \mathrm{a}$ & $8 \mathrm{a}$ \\
\hline Control & $12 \mathrm{c}$ & $88 \mathrm{a}$ & $0 \mathrm{a}$ & $32 a b$ & $21 a b$ & $3 \mathrm{bc}$ & $4 \mathrm{a}$ & $8 a$ \\
\hline \multicolumn{9}{|l|}{2010} \\
\hline Annual clip & $38 \mathrm{a}$ & $62 \mathrm{bc}$ & $0 \mathrm{a}$ & $73 \mathrm{a}$ & $12 d$ & $2 c$ & $1 \mathrm{a}$ & $4 \mathrm{~b}$ \\
\hline Biennial clip & $29 a b$ & $68 a b c$ & $0 \mathrm{a}$ & $38 \mathrm{bc}$ & $24 \mathrm{bc}$ & $6 \mathrm{a}$ & $4 \mathrm{a}$ & $6 \mathrm{~b}$ \\
\hline Triennial clip & $18 b$ & $82 \mathrm{a}$ & $0 \mathrm{a}$ & $45 \mathrm{~b}$ & $29 a b c$ & $1 \mathrm{c}$ & $1 \mathrm{a}$ & $6 \mathrm{~b}$ \\
\hline Annual fire & $40 \mathrm{a}$ & $58 \mathrm{c}$ & $1 \mathrm{a}$ & $74 \mathrm{a}$ & $9 d$ & $3 \mathrm{bc}$ & $2 a$ & $6 \mathrm{~b}$ \\
\hline Biennial fire & $18 \mathrm{~b}$ & $74 a b c$ & $1 \mathrm{a}$ & $41 \mathrm{bc}$ & $22 \mathrm{c}$ & $7 \mathrm{a}$ & $2 a$ & $11 \mathrm{a}$ \\
\hline Triennial fire & $17 \mathrm{~b}$ & $77 a b$ & $0 \mathrm{a}$ & $34 \mathrm{c}$ & $35 \mathrm{a}$ & $5 a b$ & $1 \mathrm{a}$ & $7 a b$ \\
\hline Control & $20 \mathrm{~b}$ & $76 a b$ & $0 \mathrm{a}$ & $41 \mathrm{bc}$ & $30 a b$ & $3 \mathrm{bc}$ & $1 \mathrm{a}$ & $8 a b$ \\
\hline \multicolumn{9}{|l|}{2011} \\
\hline Annual clip & $72 a b$ & $23 \mathrm{~cd}$ & $1 \mathrm{a}$ & $73 \mathrm{a}$ & $0 \mathrm{~b}$ & $0 \mathrm{~b}$ & $14 \mathrm{a}$ & $6 \mathrm{c}$ \\
\hline Biennial clip & 58 bc & 37 bc & $2 a$ & 49 bc & $2 b$ & $2 a b$ & $23 a$ & $9 \mathrm{bc}$ \\
\hline Triennial clip & $38 \mathrm{~d}$ & $52 \mathrm{ab}$ & $5 a$ & $45 \mathrm{bc}$ & $24 \mathrm{a}$ & $2 a b$ & $1 \mathrm{~b}$ & $10 \mathrm{bc}$ \\
\hline Annual fire & $80 \mathrm{a}$ & $18 d$ & $0 \mathrm{a}$ & $80 a$ & $1 \mathrm{~b}$ & $0 \mathrm{~b}$ & $3 \mathrm{~b}$ & $9 \mathrm{bc}$ \\
\hline Biennial fire & $57 \mathrm{~b}$ & $32 \mathrm{~cd}$ & $10 \mathrm{a}$ & $54 \mathrm{~b}$ & $2 b$ & $4 \mathrm{a}$ & $4 \mathrm{~b}$ & $27 \mathrm{a}$ \\
\hline Triennial fire & $37 \mathrm{~d}$ & $56 a$ & $1 \mathrm{a}$ & $43 \mathrm{bc}$ & $27 \mathrm{a}$ & $2 a b$ & $1 \mathrm{~b}$ & $9 \mathrm{bc}$ \\
\hline Control & $42 \mathrm{~cd}$ & $56 \mathrm{a}$ & $0 \mathrm{a}$ & $41 \mathrm{c}$ & $24 \mathrm{a}$ & $3 \mathrm{a}$ & $3 \mathrm{~b}$ & $12 \mathrm{~b}$ \\
\hline \multicolumn{9}{|l|}{2012} \\
\hline Annual clip & $69 a b$ & $23 b c$ & $0 \mathrm{a}$ & $81 \mathrm{a}$ & $5 \mathrm{c}$ & $1 \mathrm{~cd}$ & $0 \mathrm{a}$ & $3 a$ \\
\hline Biennial clip & $59 \mathrm{bc}$ & $38 \mathrm{ab}$ & $5 a$ & $63 \mathrm{~b}$ & $22 b$ & $5 \mathrm{~b}$ & $0 \mathrm{a}$ & $1 \mathrm{a}$ \\
\hline Triennial clip & $54 \mathrm{bc}$ & 26 bc & $8 a$ & $64 \mathrm{~b}$ & $18 b$ & $0 \mathrm{~d}$ & $0 \mathrm{a}$ & $3 a$ \\
\hline Annual fire & $79 a$ & $15 \mathrm{c}$ & $0 \mathrm{a}$ & $87 \mathrm{a}$ & $2 c$ & $1 \mathrm{~cd}$ & $0 \mathrm{a}$ & $1 \mathrm{a}$ \\
\hline Biennial fire & 56 bc & $30 \mathrm{bc}$ & $13 \mathrm{a}$ & $62 \mathrm{~b}$ & $19 \mathrm{~b}$ & $8 a$ & $0 \mathrm{a}$ & $2 \mathrm{a}$ \\
\hline Triennial fire & $64 a b c$ & $24 \mathrm{bc}$ & $7 \mathrm{a}$ & $58 \mathrm{~b}$ & $16 \mathrm{~b}$ & $3 \mathrm{bc}$ & $0 \mathrm{a}$ & $5 a$ \\
\hline Control & $46 \mathrm{c}$ & $50 \mathrm{a}$ & $0 \mathrm{a}$ & $37 \mathrm{c}$ & $44 \mathrm{a}$ & $8 \mathrm{a}$ & $0 \mathrm{a}$ & $1 \mathrm{a}$ \\
\hline$P$ & 0.02 & $<0.01$ & 0.17 & $<0.01$ & $<0.01$ & 0.01 & $<0.01$ & $<0.01$ \\
\hline Stderr $^{2}$ & 8.7 & 8.5 & 2.8 & 5.2 & 3.7 & 1.4 & 2.1 & 2.3 \\
\hline
\end{tabular}

${ }^{1}$ Means within a column and year followed by different letters are significantly different at $P<0.05$.

${ }^{2}$ Stderr indicates standard error of the mean.

\section{RESULTS}

\section{Weather}

Total study period (April-August) precipitation was 76\%, $140 \%, 95 \%$, and $89 \%$ of the $30-y r$ average in 2009,2010 , 2011, and 2012, respectively (Table 1). Precipitation in 2012 was $89 \%$ of normal; however, rainfall during the majority of the warm-season growing period (June-August) was only $48 \%$ of the $30-$ yr average (Table 1). In contrast, 2010 received $175 \%$ of the 30-yr average precipitation, and 2009 and 2011 received $82 \%$ and $86 \%$ during this same period, respectively (Table 1 ). Average monthly temperature during the study period was $94 \%, 113 \%, 106 \%$, and $113 \%$ of the $30-y r$ average in 2009 , 2010, 2011, and 2012, respectively. April monthly average temperature was warmer in 2010 and 2012 compared with 2009 and 2011 (Table 2). Monthly average temperature during the study period was at or near normal in 2009 (Table 2). In contrast, 2012 was above the 30-yr average every month except August (Table 2). Average July temperature in 2011 and 2012 were $109 \%$ and $114 \%$ above the $30-y r$ average, respectively (Table 2).

\section{Interseeded Site}

Big Bluestem Cover. The defoliation treatment by year interaction for big bluestem canopy cover (Table 3) was attributed to the biennial or triennial treatments that were reapplied in different years during the 4-yr study when compared 


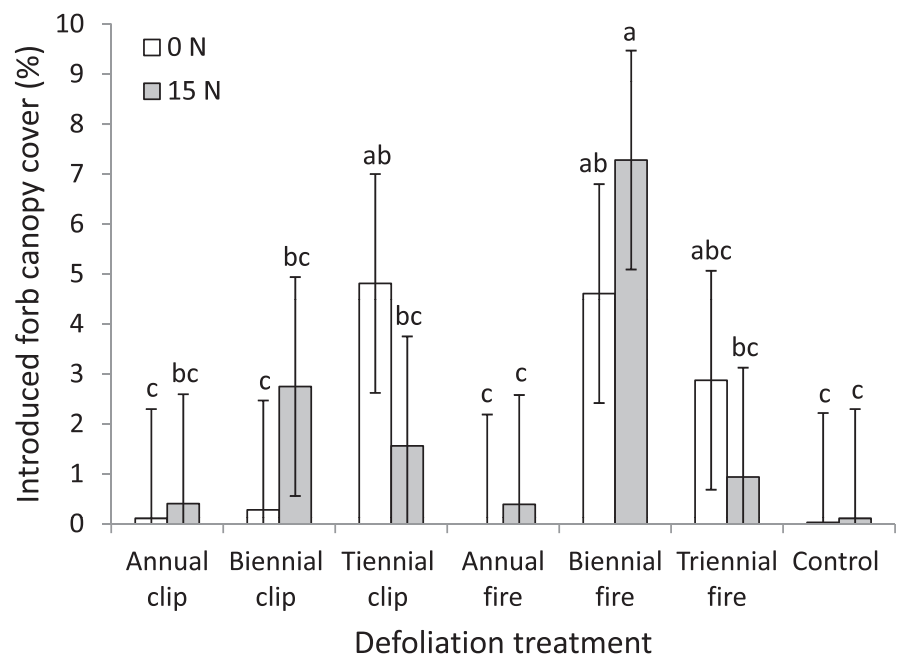

Figure 1. Introduced forb canopy cover (\%) defoliation treatment by nitrogen interaction $(P=0.02) 0$ or $15 \mathrm{~kg} \mathrm{~N} \cdot \mathrm{ha}^{-1}$ averaged over years at the interseeded site located in east-central South Dakota. Columns with different letters are significantly different $(P<0.05)$.

with the annual treatments or control. For example, in 2009 the annual, biennial, and the triennial clip treatments had similar big bluestem cover, whereas in 2010 the cover in the annual clip plot was greater than either the biennial or triennial clip plots, which were not applied that year (Table 4). In a second example, the biennial treatment, which was reapplied in 2011, had similar cover when compared to the annual clip treatment, whereas the triennial clip treatment had lower big bluestem canopy cover (Table 4). In 2012 when the triennial clip treatment was reapplied, the annual, biennial, and triennial clip treatments had similar cover (Table 4). This same pattern was observed with the fire treatments except the annual fire treatment usually had greater big bluestem cover than the biennial or triennial fire treatments (Table 4). Big bluestem cover was consistently greater in the annual clip or annual fire treatments compared with the undefoliated control treatment every year. The percent canopy cover of big bluestem in the control treatment increased over the 4-yr study period. This was positively related to average monthly July temperature over the study (big bluestem canopy cover $=-105.86 \pm 6.40 \times$ July temperature; $\left.r^{2}=0.92, P=0.04\right)$.

Introduced Cool-Season Grass Cover. Because the site's plant community approximated a binary mixture of big bluestem and introduced cool-season grasses, the pattern observed for the cool-season grass cover was opposite of the warm season cover. The defoliation treatment by year interaction for introduced cool-season grass canopy cover (Table 3) was attributed to a decrease in cool-season grass canopy cover to a greater extent for reapplications of biennial or triennial treatments relative to other treatments over the previous year (Table 4). The annual clip or annual fire treatments were consistently lower in introduced cool-season grass canopy compared with the control except in 2010 (Table 4). Also, introduced cool-season grass canopy cover decreased by year in the control treatment and was inversely related to July temperature (introduced coolseason grass canopy cover $=214.69-6.54 \times$ July temperature; $r^{2}=0.95, P=0.02$ ).
Introduced Forb Cover. Introduced forb canopy cover was $1 \%$ or less for the first $2 \mathrm{yr}$ of the study but increased in some treatments in 2011 and 2012 (Table 4). We observed that Canada thistle (Cirsium arvense [L.] Scop.) was the most common introduced forb at the interseeded site. The defoliation treatment by nitrogen interaction resulted from the inconsistency between biennial and triennial clip and fire treatments (Fig. 1). The annual clip, annual fire, and control treatments had less than $0.25 \%$ introduced canopy cover for either 0 or $15 \mathrm{~kg} \mathrm{~N} \cdot \mathrm{ha}^{-1}$ (Fig. 1).

\section{Native Prairie Site}

Native Warm-Season Grass Cover. A defoliation treatment by year interaction for native warm-season grass canopy cover (Table 3) was observed. All the treatments had about the same canopy cover in 2009 at the start of the experiment, but in subsequent years the annual clip or annual fire treatments had greater warm-season canopy cover than the other treatments (Table 4). Biennial and triennial defoliation treatments had similar warm season canopy cover in 2012, which was $20 \%$ higher than the untreated plots, but less than cover in annual treatments (Table 4).

Introduced Cool-Season Grass Cover. The defoliation treatment by year interaction for introduced cool-season grass canopy cover (Table 3) was attributed to the treatments having nearly the same canopy cover in 2009 at the start of the experiment, but in subsequent years the annual clip or annual fire treatments had the lowest amount of introduced cool-season grass canopy cover when compared with the other treatments (Table 4). In 2011 when the biennial defoliation treatments were reapplied they were not different than the annual treatments but were less than the control treatment (Table 4). In 2012 when the triennial defoliation treatments were reapplied, they had similar cover as the biennial treatments, but lower cover than the control and greater cover than the annual treatments (Table 4). Over the 4 yr of this study, introduced cool-season grass canopy cover for the control increased and was positively related to average June temperature (introduced cool-season grass canopy cover$-82.42+5.75 \times$ June temperature; $r^{2}=0.94 ; P=0.02$ ).

The defoliation treatment by nitrogen interaction on introduced cool-season grass canopy cover was a result of inconsistencies among the clip and fire defoliation treatments and the control (Fig. 2). The addition of $15 \mathrm{~kg} \mathrm{~N} \cdot \mathrm{ha}^{-1}$ increased introduced cool-season canopy cover in the control, whereas 0 or $15 \mathrm{~kg} \mathrm{~N} \cdot \mathrm{ha}^{-1}$ had no effect among the other defoliation treatments except for the triennial clip treatment (Fig. 2).

Native Cool-Season Grass Cover. The defoliation treatment by year interaction for native cool-season grass canopy cover (Table 3) resulted from the fact that defoliation treatments tended to decrease native cool-season grass canopy cover the year that they were reapplied and increased the cover relative to the control in years they were not applied (Table 4).

Introduced Forb Cover. The defoliation treatment by year interaction (Table 3) was attributed to all treatments in 2009, 2010, and 2012 having similar introduced forb canopy cover; however, the annual and biennial clip treatments had greater 


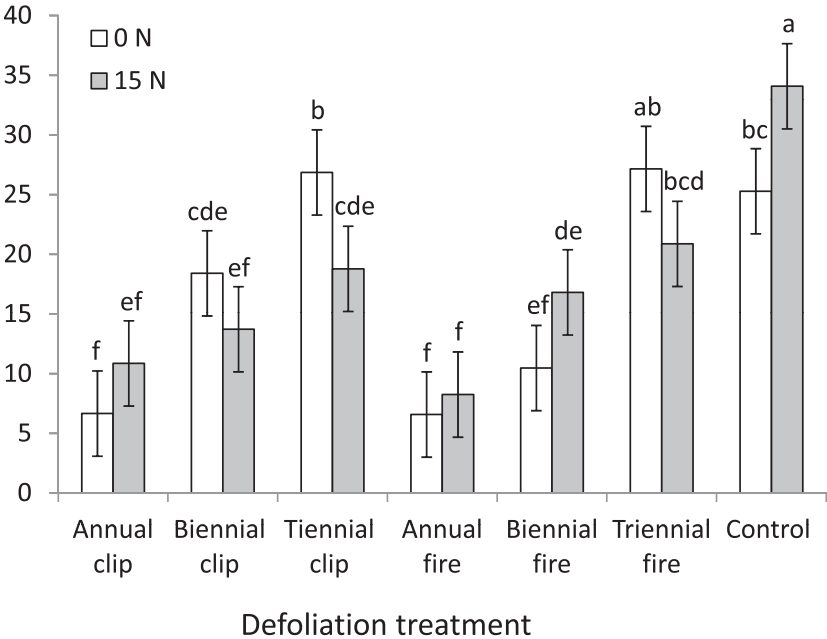

Figure 2. Introduced cool-season grass canopy cover (\%) defoliation treatment by nitrogen interaction $(P=0.03) 0$ or $15 \mathrm{~kg} \mathrm{~N} \cdot \mathrm{ha}^{-1}$ averaged over years at the native prairie site located in east-central South Dakota. Columns with different letters are significantly different $(P<0.05)$.

introduced forb canopy cover than the other treatments in 2011 (Table 4).

Native Forb Cover. The defoliation treatment by year interaction (Table 3) was a result of the fact that in 2009 and 2012 all treatments has similar native forb canopy cover; however, the biennial fire treatment had greater native forb canopy cover than the annual, biennial, and triennial clip treatments, and annual fire treatments in 2010 and was greater than the other treatments in 2011 (Table 4). The nitrogen main effect resulted in $1.6 \%$ greater native forb canopy cover for the $15 \mathrm{~kg} \mathrm{~N} \cdot \mathrm{ha}^{-1}$ treatment $(8.1 \%$; $\mathrm{SE}=0.71 \%)$ compared with the $0 \mathrm{~kg} \mathrm{~N} \cdot \mathrm{ha}^{-1}$ treatment $(6.5 \%$; SE $=0.71 \%)$.

\section{DISCUSSION}

Results support the hypothesis that repeated clipping during the month of May would be equal to the effect of spring burning in reducing introduced cool-season grass cover and increasing native warm-season grass cover, irrespective of site (Table 4). These results are consistent with experiments that showed mowing maintained native species dominance and richness and reduced exotic species (Old 1969; Bobbink et al. 1987; Fynn et al. 2004). Therefore, intensive grazing during May, while coolseason grasses are in their rapid growth phase, as demonstrated by Smart and Owens (2008), could be effective in improving native prairie if burning is not possible due to weather constraints or logistical problems with applying prescribed fire.

Annual clipping and annual fire were observed to have a greater impact on native warm-season and introduced coolseason canopy cover than either biennial or triennial applications. However, in the years when the biennial or triennial treatments were reapplied at the interseeded site, grass cover was similar to the annual treatments (Table 4). This was not the case at the native prairie site. The annual treatments consistently had the greatest native warm-season grass canopy cover and the least introduced cool-season grass cover than the other treatments except in the first year when all the treatments were initiated and in 2011 when the biennial treatments were reapplied (Table 4). This pattern, where the native warm-season grass decreases as introduced cool-season grass increases in years where clipping or burning is not applied, has been shown by Engle and Bultsma (1984) and Willson and Stubbendieck (2000).

Whereas repeated annual spring burning has been shown to have positive ecosystem responses, e.g., increased native warmseason grass cover, increased forbs and shrubs, and decreased abundance of introduced cool-season grass (Anderson et al. 1970; Launchbaugh and Owensby 1978; Hover and Bragg 1981; Towne and Owensby 1984; Becker 1988; Mitchell et al. 1996; Smart and Owens 2008), frequent fire can have negative environmental effects. Annual burning regimes can adversely impact insects (Swengel 2001; Panzer 2002) and birds (Brawn et al. 2001) and have been observed to reduce vegetation species diversity (Abrams and Hulbert 1987) in grasslands. In Kansas, long-term repeated annual spring burning $(>50 \mathrm{yr})$ did not reduce total forage production (Towne and Owensby 1984). However, after $12 \mathrm{yr}$ of repeated annual burning, soil bulk density, electrical conductivity, and some macro- and micronutrients decreased compared with unburned tallgrass prairie in Arkansas (Brye 2006). Svedarsky et al. (1986) showed that $13 \mathrm{yr}$ of annual or biennial burning reduced Kentucky bluegrass by $50 \%$ and increased big bluestem 3-fold and little bluestem 4-fold compared with the unburned control. Their results reached a plateau after the first 6 yr (Svedarsky et al. 1986). Therefore, repeated annual burning or clipping may not provide new benefits in the long term. Once desired vegetation effects are achieved with annual burning, a shift to biennial or triennial cycles may be preferred.

Most native cool-season grasses are bunchgrasses and can be negatively impacted by fire (Engle and Bultsma 1984). Indeed, we observed that native cool-season grasses were negatively impacted by annual burning treatments at the native prairie site. This research goes a step further to show that native cool-season grass cover has a similar response to annual repeated clipping. In the years when biennial treatments were not applied, the canopy cover of native cool-season grass rebounded to levels equal to or greater than the control (Table 4). In mixed-grass prairie of western South Dakota, green needlegrass, a cool-season bunch grass, did not recover to preburn levels after a single burn even after 3 yr (Whisenant and Uresk 1990). In northern tallgrass prairie, native cool-season grass recovery was faster, just $1 \mathrm{yr}$ under drought conditions (Engle and Bultsma 1984). In order to maintain native cool-season grasses, burning or clipping every other year may be needed.

Our data had mixed results concerning our hypothesis that defoliation treatments would not affect introduced or native forb canopy cover. At the interseeded site introduced forbs were not affected by defoliation treatment, but both introduced and native forbs were affected by defoliation treatments at the native prairie site (Table 4). At the interseeded site, introduced forbs made up less than $6 \%$ of the total canopy cover and had a high standard error (Table 4). At the native prairie site, only a few defoliation treatments had greater forb canopy cover than the control. One confounding effect that occurred during this experiment was that the native prairie site was accidently 
sprayed via airplane with a broadleaf herbicide in 2012 to control noxious weeds in nearby pastures and undoubtedly changed the results, as evident in Table 4. Our results were similar to Grace et al. (2001).

Research has shown that small nitrogen additions (10 to $20 \mathrm{~kg}$ $\mathrm{N} \cdot \mathrm{ha}^{-1}$ ) enable introduced grasses to outcompete native species (Tilman and Wedin 1991; Vinton and Goergen 2006). Results of this study support that additions of $15 \mathrm{~kg} \mathrm{~N} \cdot \mathrm{ha}^{-1}$ can increase introduced cool-season grass canopy cover in the absence of defoliating disturbance, evident by greater cover of this functional group following nitrogen additions in undefoliated plots at the native prairie site (Table 4). Stress to the introduced grasses caused by defoliation in late spring (clipping or fire) likely prevented them from outcompeting the native warmseason grasses for the nitrogen that was applied. However, lowlevel nitrogen application in late spring was not found to increase warm-season grass cover during the study period as hypothesized, with or without disturbance. We would have expected that the warm-season grasses would be beginning their rapid elongation phase in early June at the time of nitrogen application (Mitchell et al. 1998) and would have responded positively to the $15 \mathrm{~kg} \mathrm{~N} \cdot \mathrm{ha}^{-1}$ addition, especially in the open canopy following defoliation treatments. The small amount of nitrogen may have been below a biological threshold to measure given the treatment means and the large standard errors (Table 4). In addition, the study period may not have been long enough to observe an effect.

\section{MANAGEMENT IMPLICATIONS}

In the northern tallgrass prairie, the state-and-transition model described in the loamy and thin loamy ecological sites include an invaded state with several possible native plant communities that are dominated by introduced cool-season perennial grasses (USDA NRCS 2009). Suggested management strategies to transition the invaded state to a mixed native/invaded state or plant communities within either state includes; reseeding, prescribed grazing, long-term prescribed grazing, or prescribed burning (USDA NRCS 2009). Our research showed that using spring clipping (a surrogate for grazing) or fire increased native warm-season grass and reduced introduced cool-season grass canopy cover similarly. Annual applications of either clipping or fire in just 4 yr reduced the introduced cool-season grass canopy cover to around $20 \%$ of the total in a heavy infested site (interseeded site) and to $<10 \%$ in a not so heavily infested site (native prairie site). Biennial or triennial applications were not as effective over this same period, but were less harmful to native cool-season grasses. Future increases in atmospheric deposition of inorganic nitrogen could increase introduced cool-season grass cover in idled grasslands as demonstrated in our undefoliated control at the native prairie site. However, management could nullify that effect.

\section{LITERATURE CITED}

Abrams, M. D., and L. C. Hulbert. 1987. Effect of topographic position and fire on species composition in tallgrass prairie in northeast Kansas. American Midland Naturalist 117:442-445.
Anderson, K. L., E. F. Smith, and C. E. OwensBy. 1970. Burning bluestem range. Journal of Range Management 23:81-92.

Anderson, R. H., S. D. Fuhlendorf, and D. M. Engle. 2006. Soil nitrogen availability in tallgrass prairie under the fire-grazing interaction. Rangeland Ecology \& Management 59:625-631.

BECKER, D. A. 1988. Five years of annual prairie burns. In: T. B. Bragg and J. Stubbendieck [EDS.]. Proceedings of the Eleventh North American Prairie Conference, 1989. Lincoln, NE, USA: University of Nebraska Printing. p. 163168.

Bobink, R., H. J. During, J. Schreurs, J. Willems, and R. Zielman. 1987. Effects of selective clipping and mowing time on species diversity in Chalk Grassland. Folia Geobotanica \& Phytotaxonomica 22:363-376.

Brawn, J. D., S. K. Robinson, And F. R. Thompson III. 2001. The role of disturbance in the ecology and conservation of birds. Annual Review of Ecological Systems 32:251-276.

BrYE, K. R. 2006. Soil physiochemical changes following 12 years of annual burning in a humid-subtropical tallgrass prairie: a hypothesis. Acta Oecologica 30:407413.

Clark, C. M., and D. Tilman. 2008. Loss of plant species after chronic low-level nitrogen deposition to prairie grasslands. Nature 451:712-715.

Coluins, S. L., And D. J. Gibson. 1990. Effects of fire on community structure in tallgrass and mixed-grass prairie. In: S. Collins and L. Wallace [EDS.]. Fire in North American tallgrass prairies. Norman, OK, USA: University of Oklahoma Press. p. $81-98$.

Coluins, S. L., A. K. Knapp, J. M. Briggs, J. M. Blair, E. M. Steinauer. 1998. Modulation of diversity by grazing and mowing in native tallgrass prairie. Science $280: 745-$ 747.

Cully, A. C., J. F. Cully JR., And R. D. Hiebert. 2003. Invasion of exotic plant species in tallgrass prairie fragments. Conservation Biology 17:990-998.

DiBoLL, N. 1984. Mowing as alternative to spring burning for control of cool season exotic grasses in prairie grass plantings. In: G. K. Clambey and R. H. Pemble [EDS.]. Proceedings of the Ninth North American Prairie Conference. 1986. Fargo, ND, USA: Tri-College University Center for Environmental Studies, North Dakota State University. p. 204-209.

Engle, D. M. and P. M. Bultsma. 1984. Burning of northern mixed prairie during drought. Journal of Range Management 37:398-401.

Fynn, R. W. S., C. D. Morris, AND T. J. Edwards. 2004. Effect of burning and mowing on grass and forb diversity in a long-term grassland experiment. Applied Vegetation Science 7:1-10.

Gartner, F. R., And C. H. Sieg. 1996. South Dakota rangelands: more than a sea of grass. Rangelands 18:212-216.

Gillen, R. L., D. Rollins, AND J. F. StRitzke. 1987. Atrazine, spring burning, and nitrogen for improvement of tallgrass prairie. Journal of Range Management 40:444-447.

Grace, J. B., M. D. Smith, S. L. Grace, S. L. Collins, and T. J. Stohlgren. 2001. Interactions between fire and invasive plants in temperate grasslands of North America. In: K. E. M. Galley and T. P. Wilson [EDs.]. Proceedings of the Invasive Species Workshop: the Role of Fire in the Control and Spread of Invasive Species. Fire Conference 2000: the First National Congress on Fire Ecology, Prevention, and Management. Miscellaneous Publication No. 11. Tallahassee, FL, USA: Tall Timbers Research Station. p. 40-65.

[HPRCC] High Plains Regional Climate Center. 2012. Brookings 2 NE, South Dakota (391076) climate summary. Available at: http://www.hprcc.unl.edu/cgi-bin/ cli_perl_lib/cliMAIN.pl?sd1076. Accessed 1 November 2012.

Hover, E. I., AND T. B. BragG. 1981. Effect of season of burning and mowing on an eastern Nebraska Stipa-Andropogon prairie. American Midland Naturalist 105:13-18.

Howe, H. F. 1994a. Managing species diversity in tallgrass prairie: assumptions and implications. Conservation Biology 8:691-704.

HowE, H. F. 1994b. Response of early- and late-flowering plants to fire season in experimental prairies. Ecological Applications 4:121-133.

HowE, H. F. 1995. Succession and fire season in experimental prairie plantings. Ecology 76:1917-1925.

Howe, H. F. 2000. Grass response to seasonal burns in experimental plantings. Journal of Range Management 53:437-441.

Köchy, M., AND S. D. WiLson. 2001. Nitrogen deposition and forest expansion in the northern Great Plains. Journal of Ecology 89:807-817. 
Launchbaugh, J. L., and C. E. Owensby. 1978. Kansas rangelands: their management, based on a half century of research. Manhattan, KS, USA: Kansas Agricultural Experiment Station Bulletin 622. $56 \mathrm{p}$.

Masters, R. A., K. P. Vogel, and R. B. Mitchell. 1992. Response of central plains tallgrass prairies to fire, fertilizer, and atrazine. Journal of Range Management 45:291-295.

Mitchell, R. B., R. A. Masters, S. S. Waller, K. J. Moore, and L. J. Young. 1996. Tallgrass prairie vegetation response to spring burning dates, fertilizer, and atrazine. Journal of Range Management 49:131-136.

Mitchell, R. B., L. E Moser, K. J. Moore, and D. D. Redfearn. 1998. Tiller demographics and leaf are index of four perennial pasture grasses. Agronomy 90:47-53.

[NADP] National Atmospheric Deposition Program. 2010. NADP/NTN monitoring Iocation SD99. Available at: http://nadp.sws.uiuc.edu/sites/siteinfo. asp?id=SD99\&net=NTN. Accessed 1 November 2012.

OLD, S. M. 1969. Microclimate, fire, and plant production in an Illinois prairie. Ecological Monographs 39:355-384.

OwensBy, C. E., and E. F. Smith. 1979. Fertilizing and burning Flint Hills bluestem. Journal of Range Management 32:254-258.

Panzer, R. 2002. Compatibility of prescribed burning with the conservation of insects in small, isolated prairie reserves. Conservation Biology 16:1296-1307.

Prober, S. M., I. D. Lunt, And K. R. TheleE. 2008. Effects of fire frequency and mowing on a temperate, derived grassland soil in south-eastern Australia. International Journal of Wildland Fire 17:586-594.

Samson, J. F., AND L. E. Moser. 1982. Sod-seeding perennial grasses into eastern Nebraska pastures. Agronomy Journal 74:1055-1060.

SAS Institute. 2008. SAS software for Windows, v. 9.2. SAS Institute, Cary, NC.

SMART, A. J., AND V. N. OwENs. 2008. Interseeding warm-season grasses followed by high intensity grazing enhances pasture productivity. Online. Forage and Grazinglands doi: 10.1094/FG-2008-0815-01-RS

Smith, M. D., And A. K. Knapp. 1999. Exotic plant species in a C4-dominated grassland: invisibility, disturbance, and community structure. Oecologia 120:605-612.
Svedarsky, W. D., P. E. Buckley, And T. A. Feiro. 1986. The effect of 13 years of annual burning on an aspen-prairie ecotone in northwestern Minnesota. In: The prairie: past, present, and future: proceedings of the ninth North American Prairie Conference, 29 July-1 August 1984, Moorehead, MN, USA. Fargo, ND, USA: TriCollege University Center for Environmental Studies, North Dakota State University. p. 118-121.

Swengel, A. B. 2001. A literature review of insect responses to fire, compared to other conservation managements in open habitat. Biodiversity and Conservation 10:1141-1169.

TILMAN, D. 1990. Constraints and tradeoffs: toward a predictive theory of competition and succession. Oikos 58:3-15.

TILMAN, D., AND D. A. Wedin. 1991. Dynamics of nitrogen competition between sucessional grasses. Ecology 72:1038-1049.

ToWNE, G., AND C. OWENSBY. 1984. Long-term effects of annual burning at different dates in ungrazed Kansas tallgrass prairie. Journal of Range Management 37:392-397.

USDA NRCS. 2009. Thin loamy ecological site description R102AY012SD. Field Office Technical Guide. Available at: http://efotg.sc.egov.usda.gov/references/ public/SD/R102AY012SD_Thin_Loamy.pdf. Accessed 3 March 2013.

USDA NRCS. 2013a. Soil series classification: view by name. Available at: https:// soilseries.sc.egov.usda.gov/scname.asp. Accessed 3 March 2013.

USDA NRCS. 2013b. Web Soil Survey. Available at: http://websoilsurvey.nrcs.usda. gov/app/WebSoilSurvey.aspx. Accessed 3 March 2013.

Vinton, M. A., and E. M. Goergen. 2006. Plant-soil feedbacks contribute to the persistence of Bromus inermis in tallgrass prairie. Ecosystems 9:967-976.

WhISENANT, S. G., AND D. W. URESK. 1990. Spring burning Japanese brome in a western wheatgrass community. Journal of Range Management 43:205-208.

Willson, G. D., And J. StubBendieck. 2000. A provisional model for smooth brome management in degraded tallgrass prairie. Ecological Restoration 18:34-38.

Zhao, X., Y. XIaoYuan, Z. XIONG, Y. XIE, G. XING, S. Sh, And Z. Zhu. 2009. Spatial and temporal variation of inorganic nitrogen wet deposition to the Yangtze River Delta Region, China. Water Air Soil Pollution 203:277-289. 